\title{
PENGEMBANGAN OBJEK WISATA PANTAI KLINGKING DESA BUNGA MEKAR, KECAMATAN NUSA PENIDA, KABUPATEN KLUNGKUNG
}

\author{
I Wayan Surata ${ }^{1 *}$, Tjokorda GdeTirta Nindhia ${ }^{2}$, Tjokorda Sari Nindhia ${ }^{3}$
}

\begin{abstract}
ABSTRAK
Desa Bunga Mekar adalah salah satu desa dari 16 desa yang ada di wilayah Kecamatan Nusa Penida, Kabupaten Klungkung, yang memiliki potensi dalam bidang pariwisata. Namun potensi ini belum digarap secara optimal, karena kurang fasilitas sarana dan prasarana, disamping itu mereka juga belum memiliki keterampilan yang cukup untuk pengelolaaan. Tujuan pengabdian ini adalah untuk meningkatkan sarana yang diperlukan agar objek wisata Pantai Klingking tertata rapi, demi kenyamanan wisatawan. Beberapa kegiatan telah dilakukan melalui pelaksanaan Program Udayana untuk Masyarakat yang meliputi pembuatan pagar pengaman di tepi tebing, membuat jalan berudak, papan nama penunjuk arah, pembuatan Web Desa Bunga Mekar, pengelolaan pariwisata dan beberapa kegitan pendukung lainnya seperti penyuluhan pembuatan pakan ternak, pemeliharaan kesehatan ternak sapi dan babi serta pembuatan biogas. Pelaksanaan kegiatan ini melibatkan masyarakat lokal terutama yang berdomisili di sekitar Pantai Klingking. Semua program dapat terlaksana dengan baik karena partisipasi dan antusiasme masyarakat. Hasil kegiatan ini diharapkan dapat meningkatkan kunjungan wisata ke objek wisata Pantai Klingking, membuka peluang usaha dan peluang kerja serta meningkatkan produktivitas.
\end{abstract}

Kata kunci: pariwisata, peluang usaha, kenyamanan, pakan ternak, biogas

\begin{abstract}
Bunga Mekar village is one of the 16 villages in the District of Nusa Penida, Klungkung Regency, which has potential in the tourism sector. However, this potential has not been managed optimally, because of lack of facilities and infrastructure, besides that, they also do not have sufficient skills for management. The purpose of this activity is to improve the necessary facilities in Klingking Beach tourist attractions, for the convenience of tourists. Several activities have been carried out through the implementation of the Udayana Program for the Community, which includes the construction of a security fence on the edge of a cliff, making steps, sign directions, and making the Web of Bunga Mekar Village, tourism management and several other supporting activities such as counseling on making animal feed, maintaining the health of cattle and pigs and making biogas. The implementation of this activity involved local communities, especially those living around Klingking Beach. All programs can be carried out well because of the participation and enthusiasm of the
\end{abstract}

\footnotetext{
${ }^{1}$ Staf Pengajar Jurusan Teknik Mesin Fakultas Teknik Universitas Udayana, iwasura@gmail.com

${ }^{2}$ Staf Pengajar Jurusan Teknik Mesin Fakultas Teknik Universitas Udayana, nindhia@yahoo.com

${ }_{3}^{3}$ Staf Pengajar Fakultas Kedokteran Hewan Universitas Udayana, snindhia@yahoo.com
} 
community. The results of this activity can increase the number of tourists visit Klingking Beach, the presence of work opportunities, and increase productivity.

Keywords: tourism, business opportunities, convenience, animal feed, biogas 1. PENDAHULUAN

Desa Bunga Mekar aladalah salah satu desa dari 16 desa yang ada di wilayah Kecamatan Nusa Penida, Kabupaten Klungkung. Luas wilayah Desa Bunga Mekar 19,730 km² (1.973 ha) dengan jumlah penduduk 4.017 jiwa yang terdiri dari 2.002 laki-laki dan 2.015 perempuan, serta meliputi 1.137 Rumah Tangga (Dukcapil Klungkung, 2016). Topografi desa Bunga Mekar berbukit-bukit bergelombang di bagian Selatan, dengan ketinggian antara 5 - $250 \mathrm{~m}$ diatas permukaan laut. Kawasan Nusa Penida beriklim tropis dengan suhu berkisar antara $28^{\circ} \mathrm{C}-32^{\circ} \mathrm{C}$, memiliki curah hujan rata-rata 1562,67 $\mathrm{mm}$ setiap tahun. Pemanfaatan lahannya berupa tegalan, tanaman pangan, dan sebagian berupa semak belukar. Dengan struktur tanah bukit yang berbatu, dan iklim yang panas, menyebabkan tanaman tidak bisa tumbuh subur dan sulit hidup, sehingga Nusa Penida dikenal dengan daerah kering dan tandus.

Mata pencaharian utama penduduknya adalah pertanian dan peternakan. Pertanian dengan tanaman pangan palawija seperti jagung, ubi kayu, dan kacang-kacangan. Sedangkan tanaman perkebunan terdiri dari kelapa, jambu mente, nangka, mangga dan lain sebagainya. Ternak yang dipelihara terdiri dari ternak sapi, babi, dan ayam kampung.

Sektor pertanian tanaman pangan dan palawija yang selama ini ditekuni oleh masyarakat Nusa Penida belum dapat diandalkan untuk memenuhi kebutuhan mereka sendiri, terbukti masyarakat Nusa Penida membeli beras dan bahan pangan lainnya dari Pulau Bali. Hal ini karena kondisi Nusa Penida dengan tanah berbatu karang yang tidak subur, dan iklim dengan suhu yang sangat panas mengakibatkan tanaman tidak bisa tumbuh dengan subur.

Geliat pariwisata sudah mulai tampak di Pulau Nusa Penida, hal ini dapat dilihat semakin berkembangnya fasilitas pendukung pariwisata seperti pembangungan vila, hotel, restoran dan fasilitas lainnya. Banyak lahan yang tadinya berupa kebun kini sudah dikonversi menjadi areal bangunan. Masyarakat telah melakukan transaksi baik berupa perjanjian sewamenyewa atau jual-beli tanah kepada para investor. Tujuan kegiatan ini adalah untuk meningkatkan sarana yang diperlukan agar objek wisata Pantai Klingking tertata rapi, demi kenyamanan wisatawan, sehingga dapat meningkatkan kunjungan wisata baik domestik maupun maca negara.

\section{METODE PELAKSANAAN}

Metode yang digunakan untuk mengatasi permasalahan di Desa Bunga Mekar dapat digolongkan menjadi dua yaitu analisis data potensi objek wisata dan pembangunan infrastruktur. Untuk mencapai target luaran tersebut maka dilakukan dengan metode sebagai berikut: (a) metode survei dilakukan untuk memperoleh fakta-fakta, mencari keterangan dan pengumpulan data melalui pengamatan dan wawancara (b) bantuan bahan bangunan untuk meningkatkan fasilitas jalan dan pagar.

Model pendekatan yang dilakukan meliputi: (1) model partisipatory rural appraisal (PRA) yang menekankan keterlibatan masyarakat dalam keseluruhan kegiatan mulai dari perencanaan, pelaksanaan, dan evaluasi program pembangunan, (2) entrepreneurship capacity building yaitu meningkatkan kemampuan dan keterampilan melalui pelatihan 
dalam pengelolaan usaha industri pariwisata, (3) model participatory teknology development, memanfaatkan teknologi tepat guna yang berbasis pada ilmu pengetahuan dan kearifan budaya lokal (Adimihardja dan Hikmat, 2004).

\section{HASIL DAN PEMBAHASAN}

Pelaksanaan program secara umum meliputi dua kegiatan yaitu dalam bentuk fisik dan dalam bentuk pelatihan atau penyuluhan. Dalam bidang fisik meliputi pembuatan pagar pengaman, jalan berundak dan pembuatan tanda penunjuk arah. Dalam bidang pelatihan berupa pembuatan pakan ternak, penyuluhan kesehatan ternak sapi dan babi serta pembuatan biogas.

\subsection{Pengembangan Objek Wisata Pantai Klingking}

Desa Bunga Mekar memiliki banyak objek wisata yang terletak di bagian Selatan Pulau Nusa Penida dengan latar belakang pemandangan Samudra Indonesia. Semua objek wisata ini berada di tepi pantai yang terdiri dari 5 objek wisata yang berderet dari Barat ke Timur melalui 3 dusun yaitu:

- Pantai Pasih Uug, Pantai Pasih Andus, dan Pantai Bidadari Nusa Penida atau Angel Billabong sebutan yang diberikan oleh wisatawan mancanegara terletak di Dusun Sompang. Ketiga objek wisata ini saling berdekatan.

- Pantai Klingking dan Pura Paluang (car temple) terletak di Dusun Karang Dawa, dan

- Air Terjun Seganing yang terletak di Dusun Sebuluh.

Objek wisata ini belum dikelola dengan baik serta masih minimnya fasilitas pendukung seperti akses jalan yang belum memadai, belum adanya informasi objek, penunjuk arah yang belum cukup, kurangnya promosi, dan fasilitas pariwisata lainnya. Oleh karena itu program PUMA di Desa Bunga Mekar memprioritaskan pendampingan dalam bidang pengembangan objek wisata Pantai Klingking, dengan pertimbangan bahwa objek wisata inilah yang mempunyai jalan akses yang cukup baik.

Pantai Klingking sebetulnya berupa tebing yang sangat curam, memiliki pasir putih dengan panjang kurang dari $20 \mathrm{~m}$. Hanya petualang yang berpangalaman yang mampu turun sampai ke bawah, sementara pengunjung biasa hanya sampai diatas tebing melihat pemandangan lautan lepas Samudra Indonesia, sambil berselfie ria. Untuk menambah keamanan dan kenyamanan maka batas tebing dan jurang perlu diberi pagar pengaman untuk menghindari jatuh atau terpeleset ke tebing, seperti ditunjukkan pada Gambar 1.

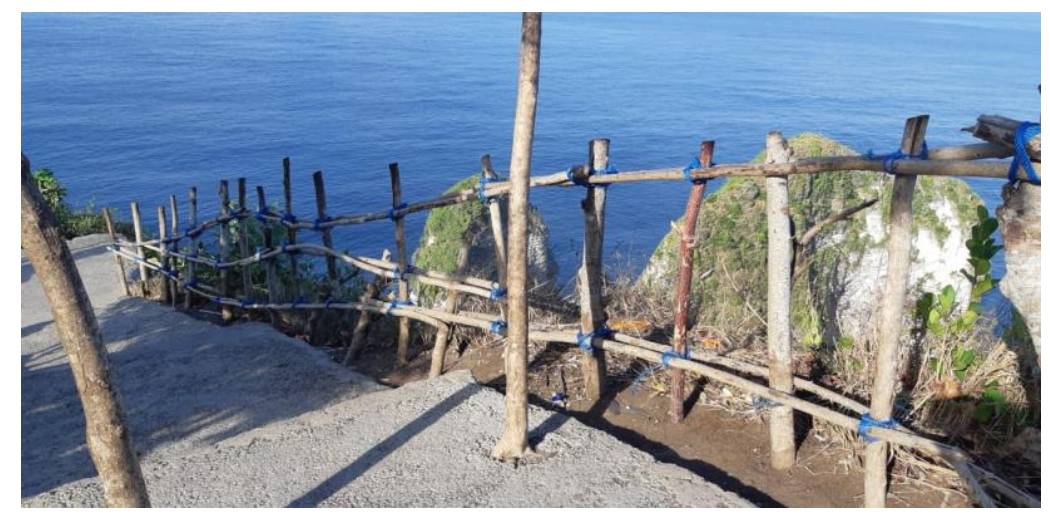

Gambar 1. Pagar pengaman 
Undakan atau tangga dibuat untuk mengatasi medan yang cukup miring, agar pengunjung tidak terpeleset terutama dimusim penghujan, seperti terlihat dalam Gambar 2. Untuk memenuhi keinginan wisatawan berselfie dengan pemandangan laut lepas disedikan penggung selfie seperti ditunjukkan pada Gambar 3.

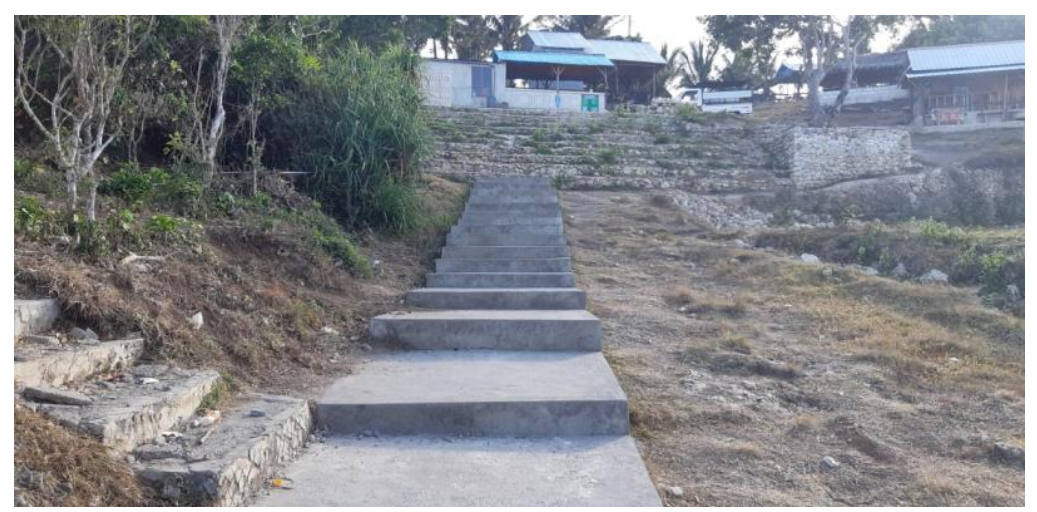

Gambar 2. Jalan berundak

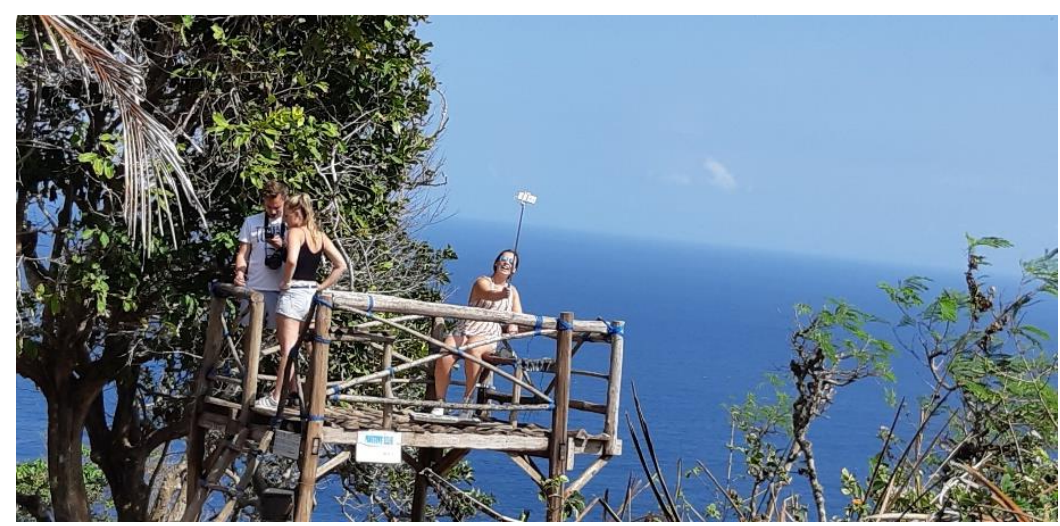

Gambar 3. Panggung selfie

\subsection{Promosi Pariwisata}

Salah satu faktor penting dalam memperkenalkan produk pariwisata adalah promosi. Promosi adalah suatu aktivitas komunikasi dari pemilik produk yang ditujukan kepada masyarakat, dengan tujuan supaya produk atau jasa, merek dan nama perusahaan dapat dikenal masyarakat sekaligus mempengaruhi masyarakat supaya mau membeli serta menggunakan produk atau jasa perusahaan.

Perencanaan kegiatan promosi pariwisata Desa Bunga Mekar dilakukan dengan pembuatan situs web objek wisata, dengan alamat: visitnusapenida.id. Situs ini berisi empat fitur utama yaitu: 1) fitur sistem informasi geografis Desa Bunga Mekar yang akan memudahkan wisatawan untuk mengetahui lokasi-lokasi yang penting seperti destinasi wisata, penginapan, rumah makan/restoran, 2) fitur galeri gambar yang akan memperlihatkan foto-foto pemandangan indah destinasi wisata di Desa Bunga Mekar seperti Pantai Klingking, Broken Sea, Angel Billabong, dan Pura Mobil, 3) fitur deskripsi destinasi wisata untuk memperjelas keadaan destinasi wisata tersebut, 4) fitur ceritra rakyat yang menjelaskan mengenai asal usul atau mitos dari objek wisata. Tampilan utama situs web desa sakti ditunjukkan dalam Gambar 4. 


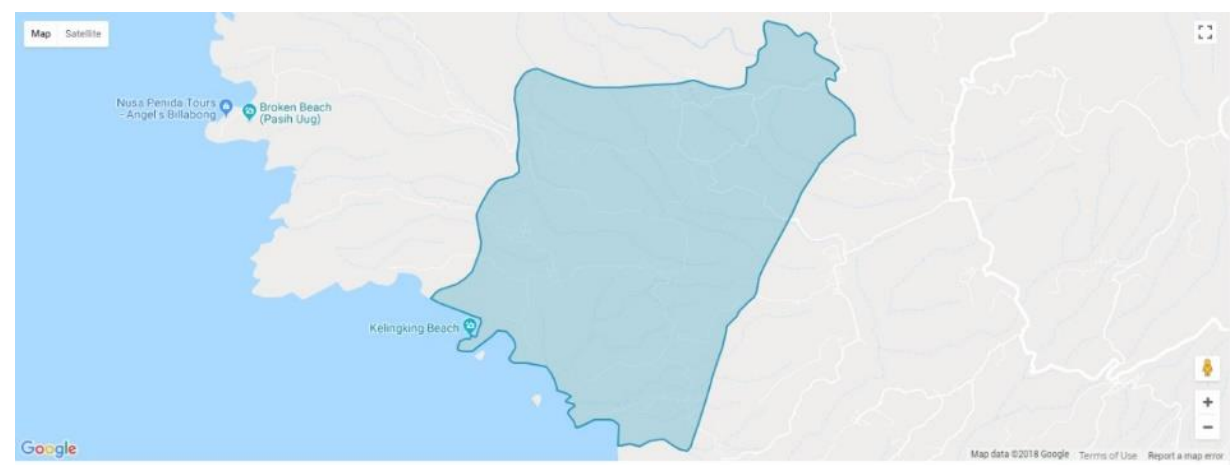

Bunga Mekar Lorem Ipsum is simply dummy text of the printing and typesetting industry. Lorem Ipsum has been the industrys standard dummy text ever since the 1500 s when an unknown printer took a galley or type since herambled wion make a type

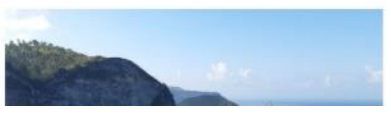

(a) Sistem informasi geografis

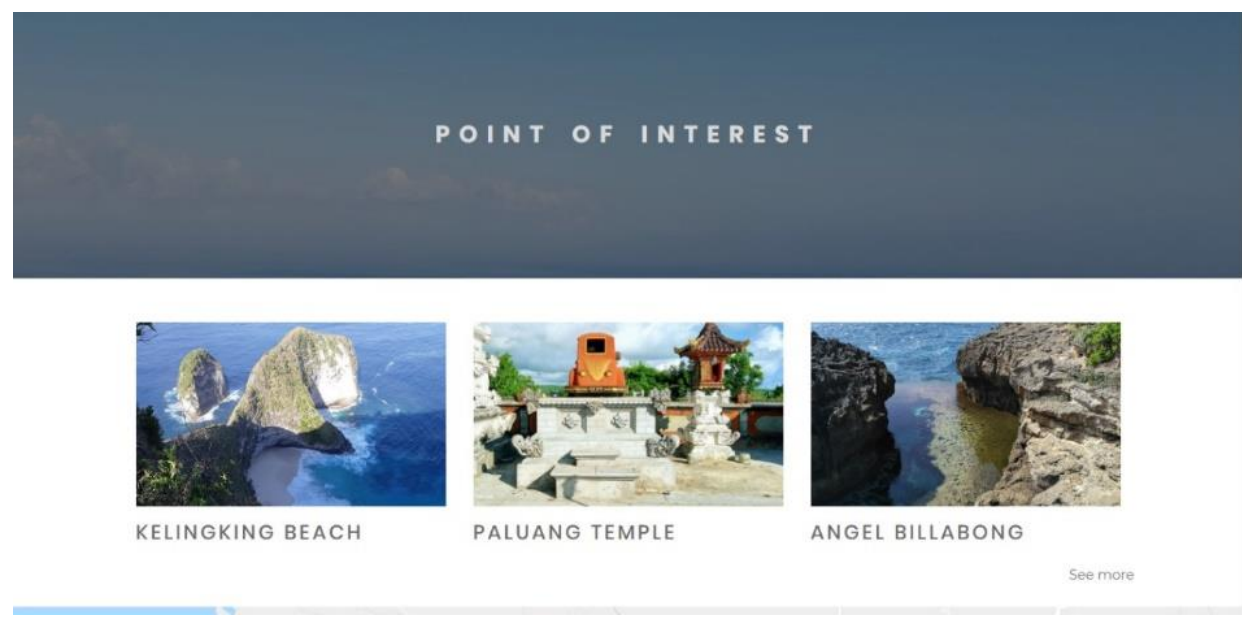

b) Objek wisata

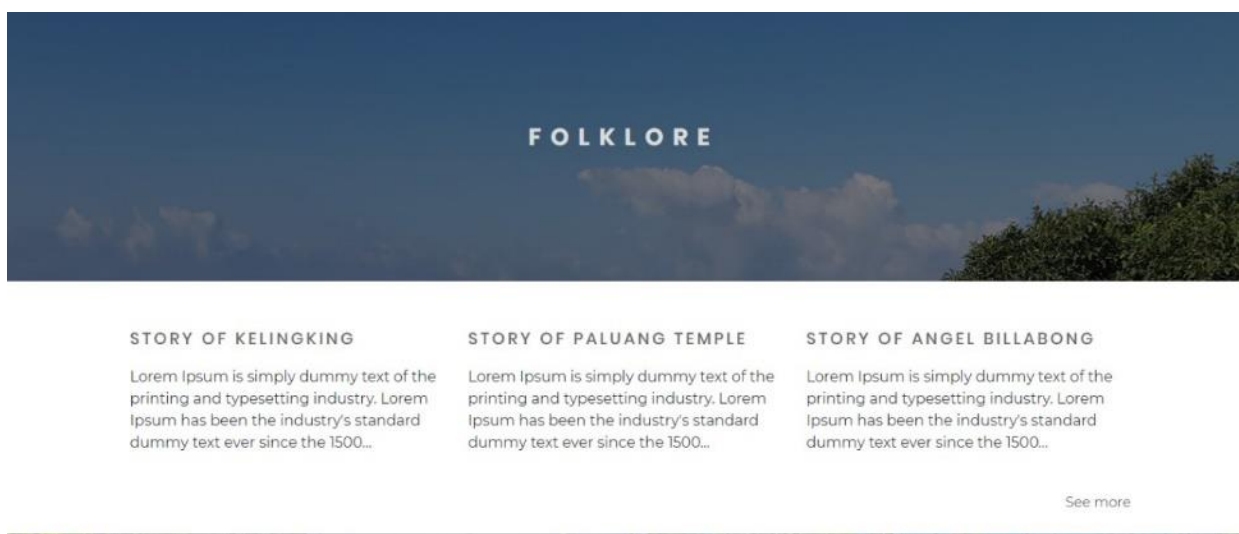

c) Ceritra rakyat

Gambar 4. Tampilan situs web: visitnusapenida.id 


\subsection{Papan Penanda Arah}

Papan penanda arah sangat penting keberadaannya untuk memberikan informasi kepada wisatawan agar tidak salah arah dalam menuju ke suatu objek wisata. Pemasangan papan penanda ini akan mempermudah dan mempercepat wisatawan mencari lokasi ataupun objek wisata yang berada di desa Bunga Mekar, seperti ditunjukkan dalam Gambar 5.

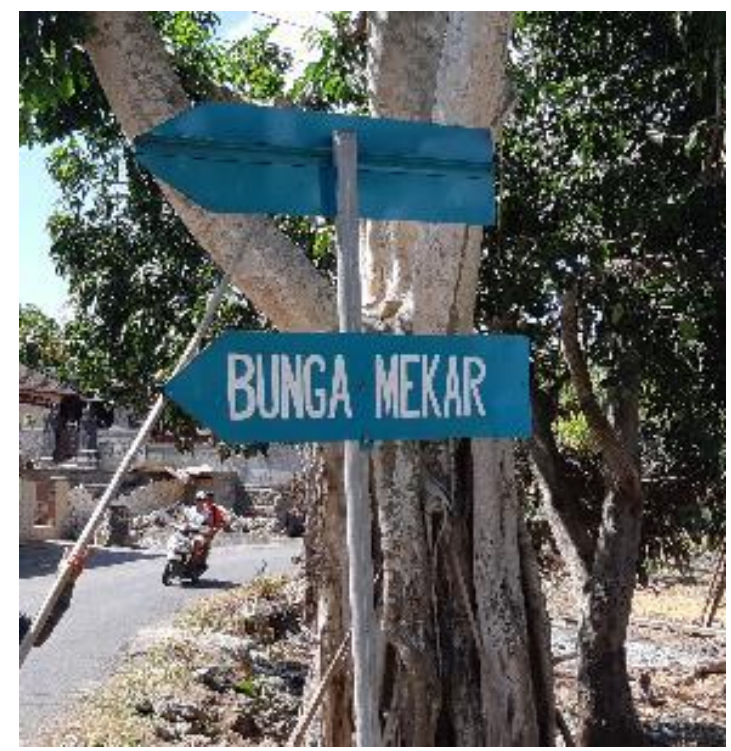

a) Menuju desa Bunga Mekar

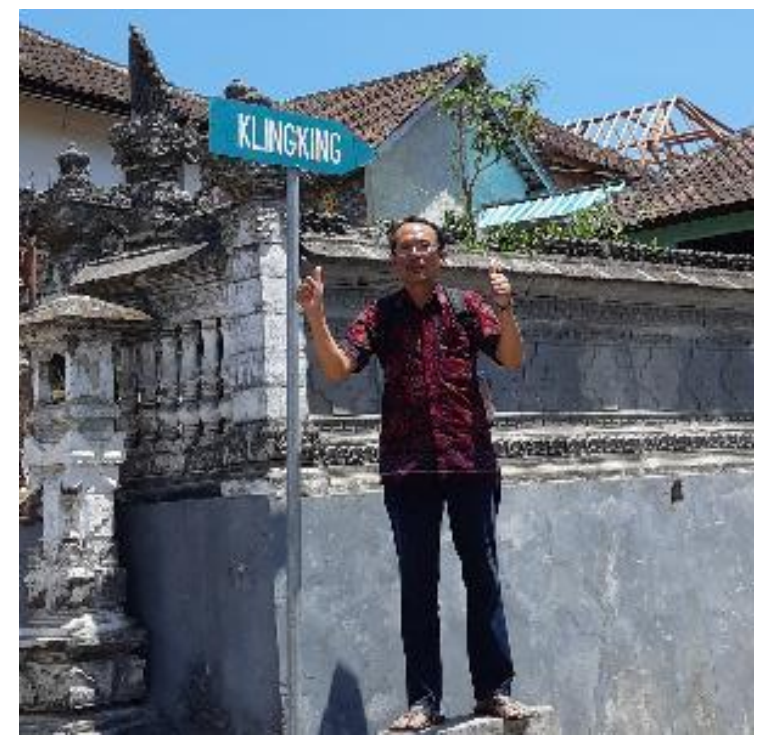

Menuju pantai Klingking

Gambar 5. Penanda arah

\subsection{Pemberdayaan Masyarakat dalam Pengembangan Pariwisata}

Desa Bunga Mekar memiliki peluang pengembangan pariwisata kerakyatan, karena ada beberapa faktor pendukung seperti:

- Memiliki kemampuan atau pengetahuan untuk mengelola sumberdaya yang dimiliki,

- Masyarakat lokal yang paling tahu dan mewarisi pengetahuan secara turun temurun tentang sumber daya lokal baik fisik maupun budaya untuk dikembangkan dalam pembangunan kepariwisataan,

- Dalam pengelolaan sumber daya masyarakat setempat lebih memiliki tanggung jawab dibandingkan mereka yang berasal dari luar,

- Masyrakat lokal akan memiliki tanggungjawab moral yang tingggi dalam pemanfaatan sumber daya yang mereka miliki.

Selanjutnya juga diidentifikasi tantangan pengembangan pariwisata kerakyatan sbb:

- Mayrakat lokal sering kurang bahkan tidak memiliki dan pemahaman tentang pembangunan kepariwisataan,

- Rendahnya minat dan kesadaran masyarakat lokal terhadap kegiatan pariwisata kerena dipandang sebagai suatu yang berasal dari luar kebudayaan mereka,

- Kualitas sumberdaya manusia (SDM) untuk masyarakat lokal yang umumnya terbatas di bidang pariwisata,

○ Faktor ekonomi dan investasi yang sangat menentukan dalam industri pariwisata sering kali tidak dimiliki oleh masyarakat lokal. 
Tantangan ini dapat diatasi dengan melakukan pelatihan dan penyuluhan secara kontinu sesuai dengan kebutuhan, misalnya kursus Bahasa Inggris untuk pemandu wisata, pelatihan menyelam dengan peralatan khusus, pembuatan souvenir dll. Teramat penting yang segera harus dilakukan adalah pembentukan Kelompok Sadar Wisata, yang befungsi sebagai fasilator yang menjembatani antara pemerintah, masyarakat pariwisata, dan pihak luar yang ingin berinvestasi. Kegiatan ceramah dan diskusi ditambpilkan dalam Gambar 6.

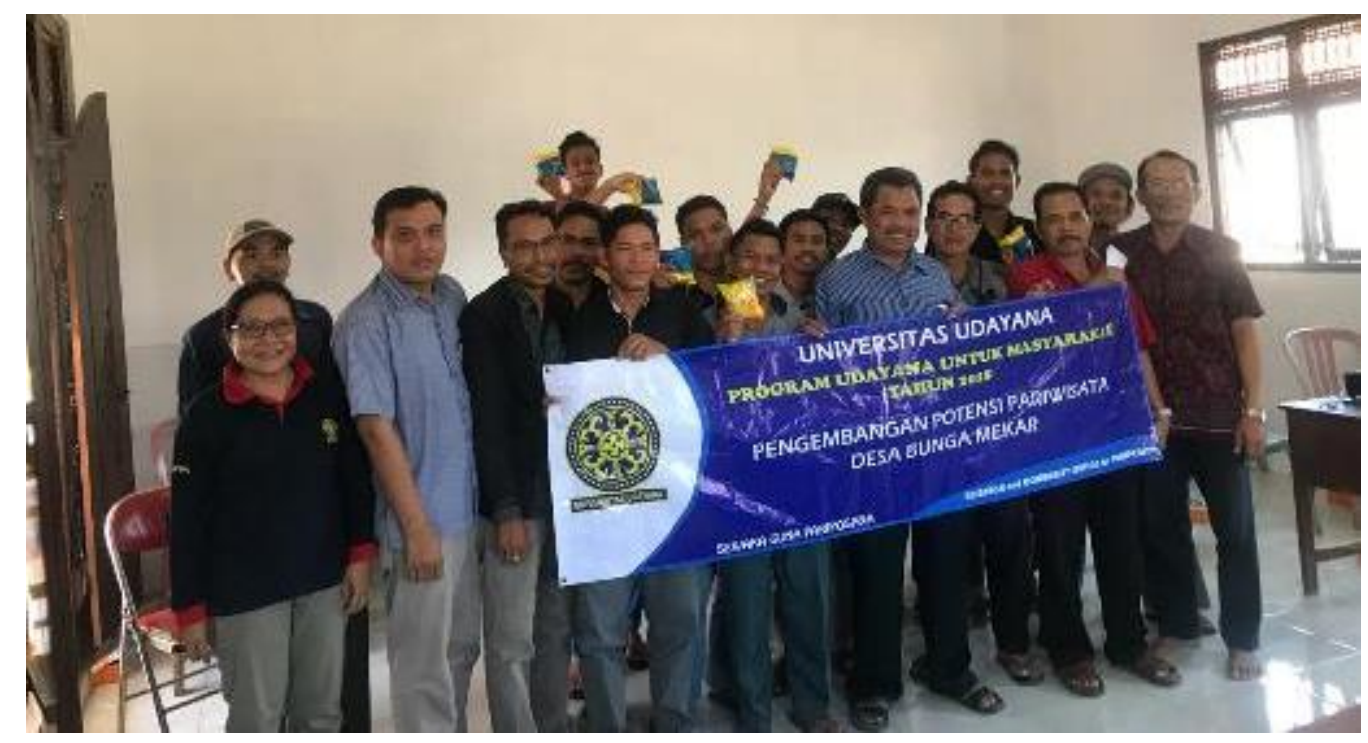

Gambar 6. Kegiatan ceramah kepariwisataan

\subsection{Penyuluhan Kesehatan Ternak}

Umumnya usaha ternak merupakan usaha pembibitan dan penggemukkan yang masuk kategori peternakan rakyat kecil dengan sumber bibit berasal dari daerah lokal sekitarnya. Usaha peternakan sapi dan babi dapat memberikan manfaat yang cukup besar dilihat dari perannya sebagai pensuplai protein hewani (Luthan, 2012). Sebagai pekerjaan sambilan masyarakat di Nusa Penida umumnya memelihara babi bagi wanita (Ibu rumah tangga), dan ternak sapi bagi kaum laki-laki. Pemeliharaan ternak di Nusa Penida masih dilakukan secara tradisional, belum ada sentuhan teknologi baik pada proses pembibitan maupun proses penggemukan. Permasalahan lainnya adalah penyediaan pakan yang sangat terbatas terutama dimusim kemarau peternak kesulitan dalam mencari pakan.

\subsection{Penyuluhan Pembuatan Pakan Ternak}

Pemeliharaan ternak ruminansia perlu memperhatikan tiga komponen utama yang saling berkaitan, yaitu: tersedianya lahan, ternak, dan pakan (Soedarjat, 2000). Ketersediaan pakan sangat tergantung pada ketersediaan lahan, dan juga iklim. Kepemilikan lahan yang sempit akan menyebabkan ketersediaan pakan menjadi sangat kurang (Ilham, 1995; Tabrany 
et al., 2003). Penyediaan pakan dari segi kualitas, kuantitas maupun kesinambungan ketersediaan hijauan pakan sangat fluktuatif sepanjang tahun di pulau Nusa Penida.

Untuk meningkatkan nilai gizi batang pisang (gedebong) perlu sentuhan ilmu pengetahuan dan teknologi, yang salah satunya dengan menerapkan teknologi biofermentasi biochast. Fermentasi adalah proses terjadinya perubahan kimia pada suatu substrat organik melalui enzim yang dihasilkan oleh mikroorganisme. Fermentasi bahan pangan adalah sebagai hasil kegiatan beberapa jenis mikroorganisne baik bakteri khamir, dan kapang (Suprihatin, 2010).

\subsection{Pembentukan Biogas}

Biogas adalah gas yang dihasilkan dari proses penguraian bahan-bahan organik oleh mikroorganisme (bakteri) dalam kondisi tanpa udara (anaerob). Proses penguraian ini dikenal dengan istilah anaerobic digestion atau pencernaan secara anaerob. Biogas diproduksi menggunakan alat yang disebut digester yang dirancang kedap udara, sehingga proses fermentasi oleh mikroorganisme dapat berjalan secara optimal (Wahyuni, 2013). Menurut Karki et al. (2005) dan Deptan (2014) kapasitas digester antara $4-8 \mathrm{~m}^{3}$ memerlukan pengisian antara 20 - $60 \mathrm{~kg}$ pengisian kotoran per hari, dan ini dapat dipenuhi dengan memelihara 2 - 3 ekor sapi dewasa. Kegiatan penyuluhan biogas ditunjukkan dalam Gambar 7.

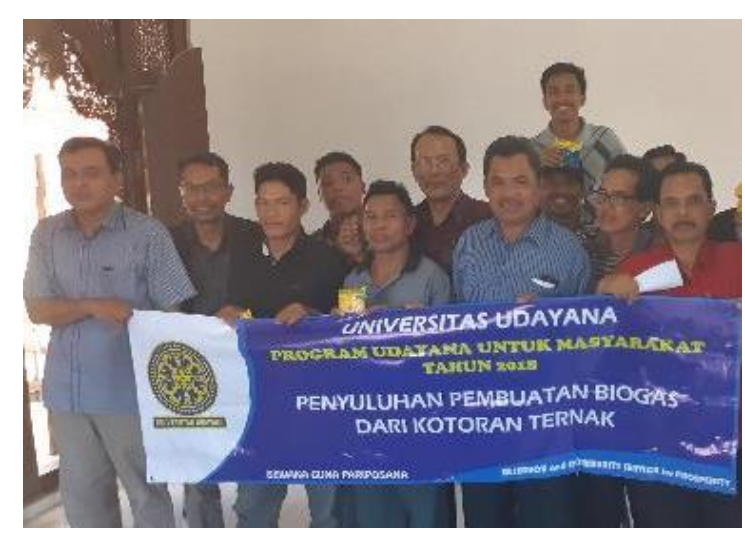

a. Penyuluhan biogas

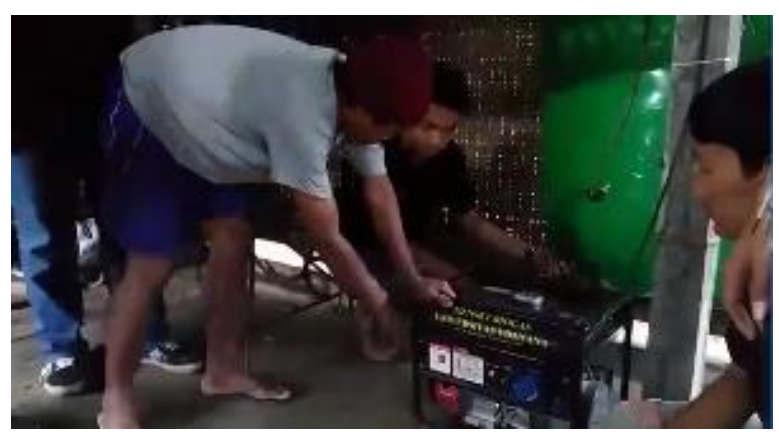

b. Genset dengan bahan bakar biogas

Gambar 7. Pengenalan teknologi biogas 


\section{KESIMPULAN}

Masyarakat Desa Bunga Mekar menyambut dengan antusias pengembangan objek wisata Pantai Klingking, hal ini dapat dilihat dari tingkat partisipasi yang cukup tinggi dalam kegiatan pembutan pagar pengaman, dan jalan yang berudak. Kegiatan ceramah dan diskusi pariwisata dengan topik Pemberdayaan Masyarakat Desa Bunga Mekar dalam Bidang Pariwisata memberi harapan baru dalam pengembangan dan pengelolaan usaha wisata, dimana masyarakat lokal ikut terlibat sebagai pelakunya. Berdasarkan hasil evaluasi kegiatan dapat disimpulkan bahwa kegiatan pelatihan dan penyuluhan dapat meningkatkan pengetahuan masyarakat Desa Bunga Mekar tentang cara pengelolaan dan promosi pariwisata. Perbaikan sarana dan prasasarana serta promosi pariwisata melalui internet secara nyata dapat meningkatkan kunjungan wisata ke Pantai Klingking.

\section{UCAPAN TERIMAKASIH}

Penulis mengucapkan terima kasih kepada Lembaga Penelitian dan Pengabdian kepada Masyarakat, Universitas Udayana, yang telah membiayai kegiatan pengabdian ini melalui Program Udayana untuk Masyarakat (PUMA) Tahun Anggaran 2018.

\section{DAFTAR PUSTAKA}

Adimihardja, K., dan Hikmat, H. 2004. Participatory Research Appraisal dalam Pelaksanaan Pengabdian kepada Masyarakat. Bandung: Humaniora Utama Press.

Deptan. 2014. Membuat Biogas dari Kotoran Ternak Sapi. Tersedia di http://cybex.deptan.go.id/ lokalita/membuat-bio-gas-dari-kotoran-ternak-sapi-1. Diakses: 12 Nov. 2014

Dewi, N.L.P.T., Sunu, I G.K.A., Sanjaya, D.B. 2014. Peranan Desa Adat dalam Pengembangan dan Pengelolaan Pantai Pandawa sebagai Kawasan Pariwisata di Desa Kutuh. Jurnal Jurusan Pendidikan PKn. Vol.2, No. 1.

Diparda Kabupaten Klungkung. 2002. Analisis Potensi Wisata Nusa Penida, Kabupaten Klungkung. Badan Pengembangan Kebudayaan dan Kepariwisataan Jurusan Manajemen Kepariwisataan Sekolah Tinggi Pariwisata Bali.

Febriyanti, N.K.O., Landrawan, I W., Sanjaya, D.B. 2014. Tingkat Perkembangan Pariwisata dan Implikasinya Terhadap Kehidupan Sosial Budaya dan Pelestarian Lingkungan di Desa Adat Unggasan Kecamatan Kuta Selatan Kabupaten Badung. Jurnal Jurusan Pendidikan PKn. Vol.2, No.1.

Karki, A.B., Shrestha, J.N., Bajgain, S. 2005. Biogas as Renewable Source of Energy in Nepal Theory and Development. BSP-Nepal, Kathmandu.

Kecamatan Nusa Penida dalam Angka. 2012. Badan Pusat Statistik Kabupaten Klungkung. Kecamatan Nusa Penida dalam Angka. 2013. Badan Pusat Statistik Kabupaten Klungkung. LIPTAN Koya Barat. 1996. Beternak Babi. Loka Pengkajian Teknologi Pertanian Koya Barat, Jayapura. 
Luthan, F. 2012. Pedoman Penataan Usaha Budidaya Babi Ramah Lingkungan. Kementerian Pertanian Direktorat Jenderal Peternakan dan Kesehatan Hewan Direktorat Budidaya Ternak.

Nindhia, T.G.T., Sucipta, I M., Surata, I W., Adiatmika, I K., Putra Negra, DNK., Trisna Negara, K.M. 2013. Processing of Steel Chips Waste for Regenerative Type of Biogas Desulfurizer. International Journal of Renewable Energy Research. 3 (1), pp. 84-87.

Pitana, I G., Diarta, I K.S. 2009. Pengantar Ilmu Pariwisata. Yogyakarta, Andi Suprihatin. 2010. Teknologi Fermentasi. UNESA University Press.

Wahyuni, S. 2013. Panduan Praktis Biogas. Jakarta, Penebar Swadaya. 